\title{
解労散が奏効した喉頭肉芽腫の一例
}

$\begin{array}{rrrrrr}\text { 関矢 } & \text { 信康 } & \text { 並木 } & \text { 隆雄 } & \text { 笠原 } & \text { 裕司 } \\ \text { 大川 } & \text { 徹 } & \text { 地野 } & \text { 充時 } & \text { 大野 } & \text { 賢二 }^{\mathrm{a}} \\ & \text { 平崎 } & \text { 能郎c } & \text { 寺澤 } & \text { 捷年 } & \end{array}$

a 千葉大学大学院医学研究院先端和漢診療学講座, 千葉， $=260-8670$ 千葉市中央区亥鼻1-8-1

b 千葉大学大学院医学研究院耳鼻咽喉・頭頸部外科学講座，千葉， $=260-8670$ 千葉市中央区亥鼻1-8-1

c 千葉大学大学院医学研究院和漢診療学講座, 千葉, $=260-8670$ 千葉市中央区亥鼻1-8-1

\section{A Case of Laryngeal Granuloma Successfully Treated with Kairosan}

\author{
Nobuyasu SEKIYA $^{\mathrm{a}}$ Takao NAMIKI $^{\mathrm{a}}$ Yuji KASAHARA $^{\mathrm{a}}$ \\ Toru OKAWA $^{\mathrm{b}}$ Atsushi CHINO ${ }^{\mathrm{a}}$ Kenji OHNO $^{\mathrm{a}}$ \\ Yoshiro HIRASAKI ${ }^{\mathrm{c}}$ Katsutoshi TERASAWA ${ }^{\mathrm{c}}$
}

a Department of Frontier Japanese Oriental (Kampo) Medicine, Graduate School of Medicine, Chiba University, 1-8-1 Inohana, Chuo-ku, Chiba 260-8670, Japan

b Department of Otolaryngology/Head and Neck Surgery, Graduate School of Medicine, Chiba University, 1-8-1 Inohana, Chuo-ku, Chiba 260-8670, Japan

c Department of Japanese Oriental (Kampo) Medicine, Graduate School of Medicine, Chiba University, 1-8-1 Inohana, Chuoku, Chiba 260-8670, Japan

\begin{abstract}
Laryngeal granulomas which grow in the rear of the vocal cords can be a refractory and recurrent condition, because of various pathogeneses and a lack of established treatment guidelines. We experienced a laryngeal granuloma case which recurred repeatedly, and was resistant to modern medicinal treatment. The laryngeal granuloma recurred after microlaryngosurgery. And though a second microlaryngosurgery and laser cauterization was done, followed by prescription of lansoprazole, tranilast, chlarithromycin and inhalation of fluticasone propionate, the laryngeal granuloma recurred once more. Thus, we tried Kampo medicines at the this time. Hangekobokuto, saishakurikkunshito and keikyososooushimbuto were stopped due to lack of efficacy on the ganuloma, and the Kampo formulation was changed to kairosan. Three weeks after changing formulation, the granuloma was no longer seen with laryngeal fiberscopy. And to-date, recurrence of the granuloma has not been confirmed. This case suggests that fatigue, body weight loss, bilateral Kyokyo-kuman (discomfort of the hypochondrium), bilateral excessive strain of abdominal muscles, pulsation of both the upper and lower navel, and tympanitic sound in upper abdomen may be clinical indications for kairosan.
\end{abstract}

Key words : laryngeal granuloma, abnormal sensation in the throat, kairosan, Kampo treatment

\section{要旨}

喉頭肉芽腫は声帯後部に生じる非特異性肉芽腫性病変で発症要因が多岐にわたるとともに確立された治療方針が ないことから，再発例が多く治療に難渋する疾患とされている。西洋医学的治療に抵抗性で再発を繰り返した特発 性喉頭肉芽腫に解労散が奏効した一例を経験した。症例は30歳, 男性。外科的切除後に再発し, 再度の外科的切除 とレーザー焼灼およびプロトンポンプ・インヒビター, トラニラスト内服, マクロライド少量持続内服療法, ステ ロイド吸入などが施行されたが再発し漢方治療を併用した。半夏厚朴湯, 柴莳六君子湯および桂姜霜草黄辛附湯で は肉芽腫には变化ないため解労散に転方し，その 3 週間後には肉芽腫は内視鏡にて消失が確認され，その後の再発 はない。本症例の経験から倦急感, 体重減少, 両側胸脇苦満, 両側腹直筋緊張, 臍上悸·臍下悸, 上腹部を中心亡 した鼓音の存在などが解労散の使用目標となりうる可能性が示唆された。

キーワード : 喉頭肉芽腫, 咽喉頭異常感, 解労散, 漢方治療 


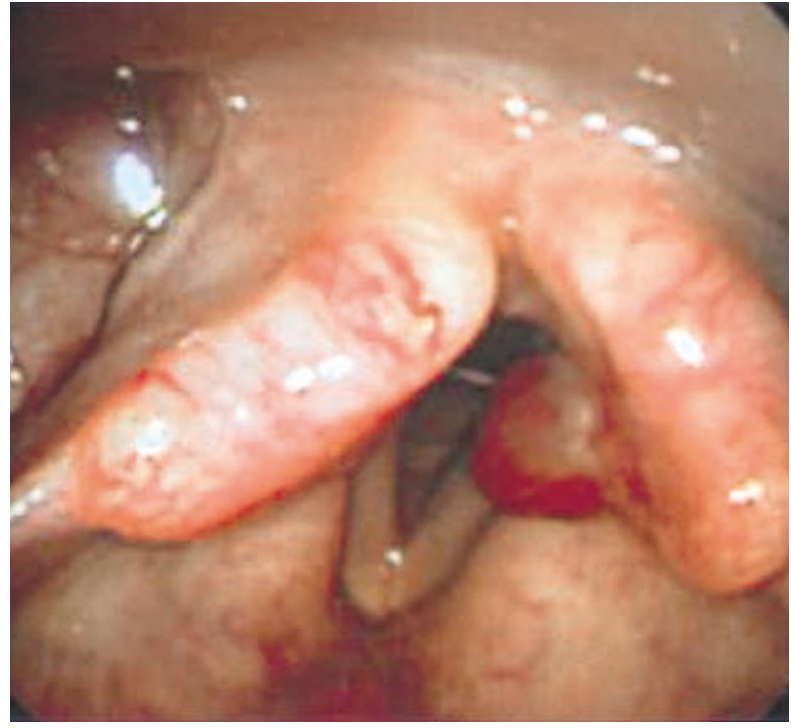

図 1 a

\section{緒言}

喉頭肉芽腫は声帯後部に生じる非特異性肉芽腫性 病変で術後性，挿管性，接触性，特発性に分類され る。喉頭疾患の中では比較的稀であり, 器質性病変 の約 1 ～％とされている ${ }^{1)}$ 。診断は内視鏡などを 用いた視診により容易であるが，発症要因が多岐に わたるとともに確立された治療方針がないことから， 再発例が多く，治療に難渋する喉頭疾患の一つとさ れている2)。

今回, 我々は種々の治療に抵抗性で再発を繰り返 した特発性喉頭肉芽腫に解労散が奏効した一例を経 験したので報告する。本報告で用いた解労散の構成， 分量等の詳細は本文の末尾に附記した。

\section{症例}

症 例：30歳，男性，公務員

主 訴：咽喉頭異常感, 嗄声

既往歴：特記すべきことなし

家族歴：父 (脳梗塞)

現病歴：2004年に縦隔腫瘍（seminoma）に対し て化学療法，放射線療法を施行され完全寛解。2005 年 3 月より咽喉頭異常感, 嗄声が出現し改善しない ため同月に近医耳鼻科を受診。左声帯腫瘍の診断で 保存的治療を受けたが改善なく，同年 5 月に全身麻 酔下でラリンゴマイクロサージェリーを施行された。 病理学的診断は炎症性肉芽であり, 悪性所見は認め られなかった。しかし術後 1 カ月目の再診時には既 に肉芽腫の再発が認められたため, レーザー焼灼術

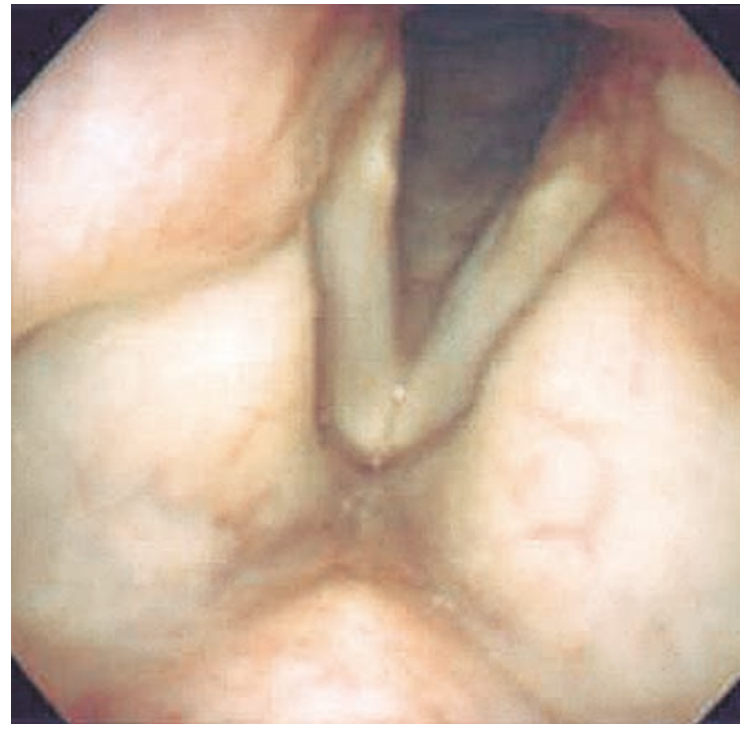

図 1 b

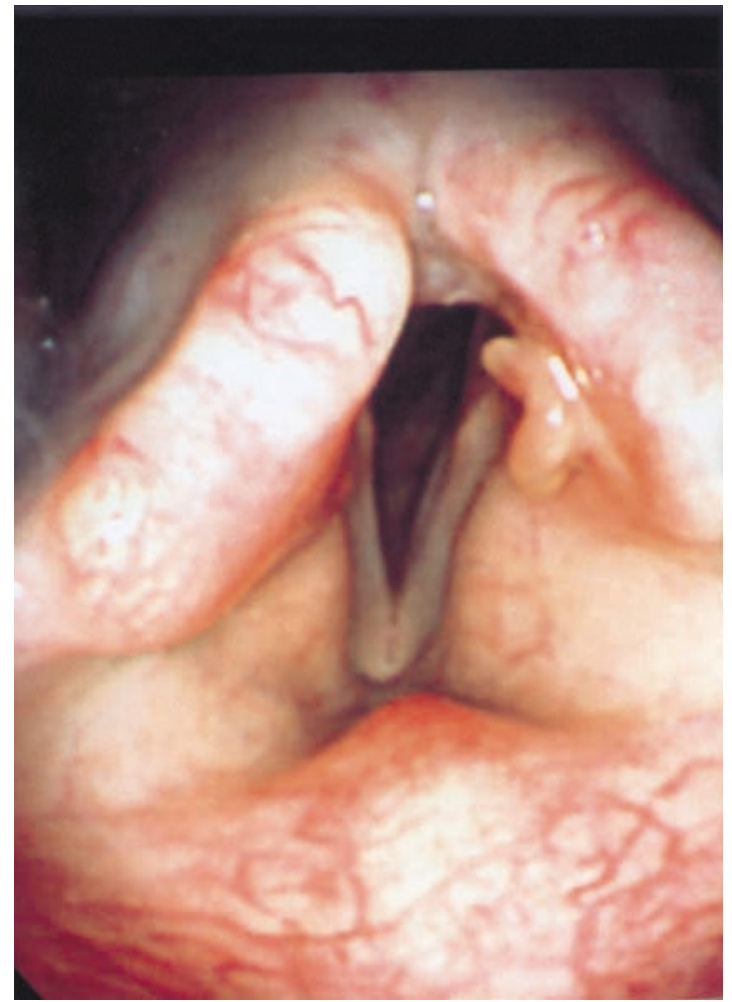

図 1 c

を目的に千葉大学医学部附属病院耳鼻咽喉 ·頭頸部 外科を紹介され 8 月に受診（図 1 a)。10月にラリ ンゴマイクロサージェリーおよびレーザー焼灼術を 施行された（図１ｂ）。その後，ランソプラゾール， トラニラスト，クラリスロマイシンの内服，プロピ オン酸フルチカゾンの吸入による治療を施行された が，2006年 1 月の再来時に肉芽腫の再発が確認され た（図１Ｃ）。このため漢方治療を希望し，同科か 

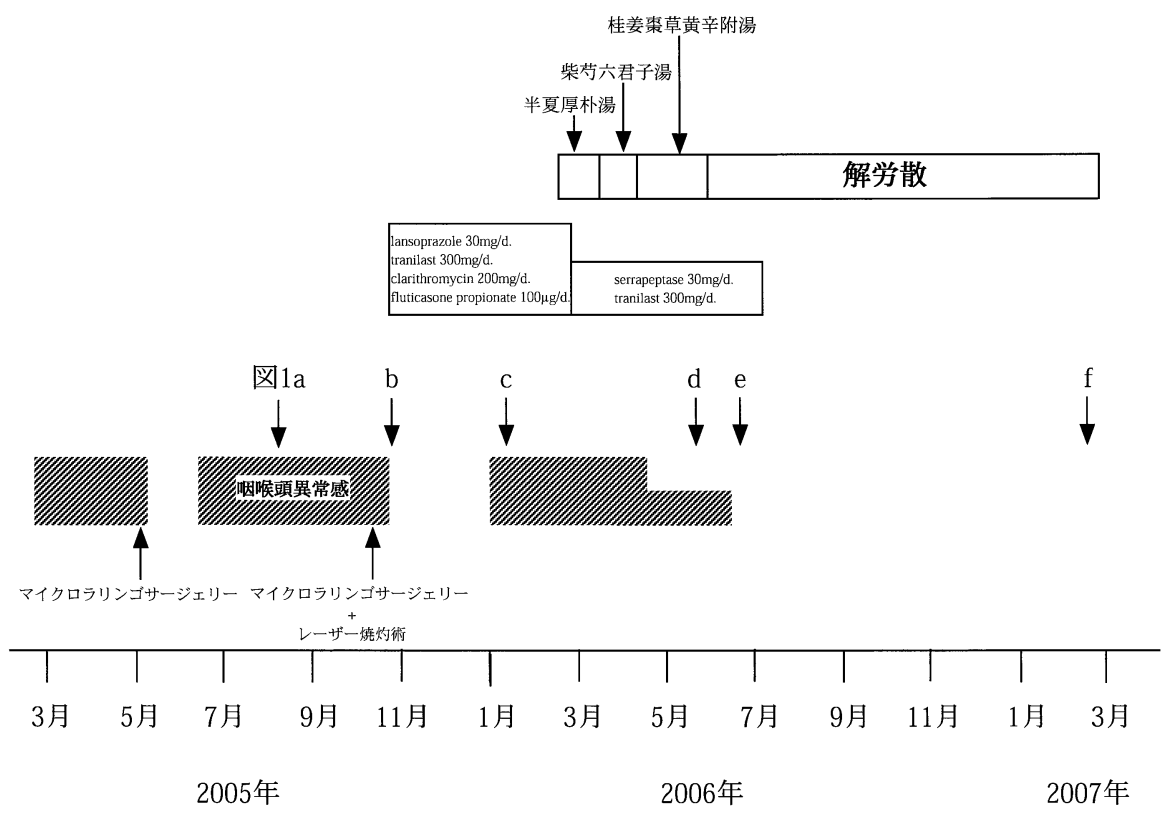

図 2

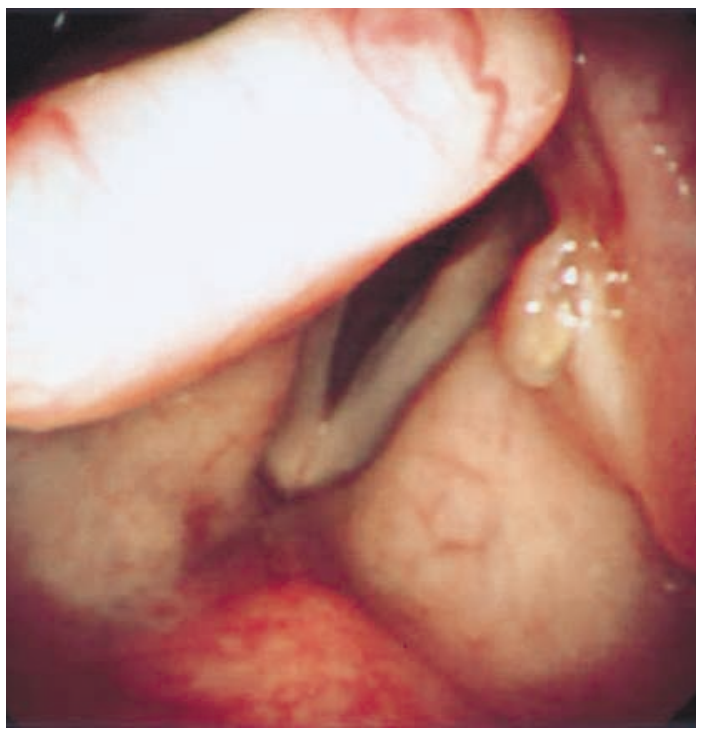

図 $1 d$

らの紹介で同年 2 月に当科を初診した。

$<$ 初診時の和漢診療学的所見 $>$

自覚症状: 咽喉頭異常感, 嗄声, 体重減少 ( 2 年 で10kg), 倦㤐感, 軽度の食思不振, 左下肢痺れ, 憂鬱，焦燥感，手足の冷え，大小便に異常なし。

他覚所見：身長 $170.2 \mathrm{~cm}$, 体重 $64 \mathrm{~kg}$, 血圧133/76 $\mathrm{mmHg}$, 脈拍 $91 /$ 分, 整, 体温 $36.6^{\circ} \mathrm{C}$ 。脈候は浮沈 中間, 弦, 緊張は中等度, やや渋。舌候で舌質は正 常紅で舌尖紅を認め乾湿中等度の微白苔に被われて いた。腹候は腹力中等度で両側腹直筋緊張, 心下㾂 鞕掞よび両側胸脇苦満が著明であり，さらに臍上悸， 臍下悸, 右側腹部 右季肋部 心窩部 左季肋部

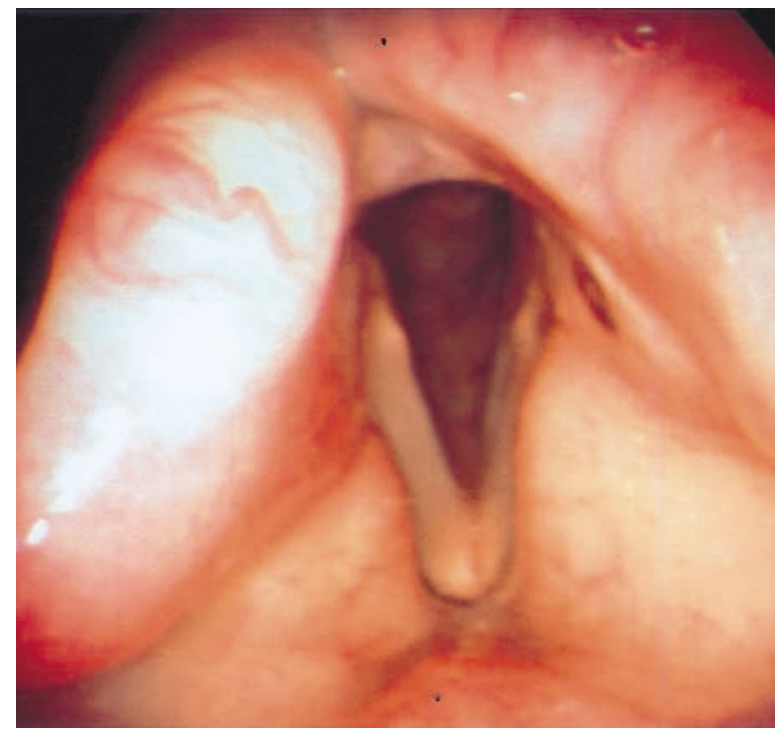

図 $1 e$

左側腹部に著明な鼓音を認めた。

<治療経過 $>$

症例の臨床経過を図 2 に示す。初診時には腹証か らは四逆散が考えられたが, 気虚, 気楿梦の症候が目 立つことから, 咽喉頭異常感を咽中采彎ととらえ半 夏厚朴湯をエキス剤にて投与した。当科初診の 1 週 間後には耳鼻科からの処方がセラペプターゼ，トラ ニラストに変更となった。しかし2006年 3 月の再診 時には症状, 肉芽腫および和漢診療学的所見はいず れも不変であった。そこで『勿誤薬室方函口訣』に

「畢竟は四逆散の証にして, 脾胃一層虚候あり, 後 世の所謂肝実脾虚と云ふ処に用ゆべし。」と記載の 
ある柴药六君子湯に転方した ${ }^{3)}$ 。同年 4 月の再来時 にも症状，所見に変化がなかったため「諸病難症㽽 疾となって治療の道が杜絶したものを，よく一転打 開する」という意味で「大気一転の方」ともいわれ る桂姜霖草黄辛附湯に転方した4)5)。転方 4 週間後に は咽喉頭異常感㧍よび左足痺れが若干軽快したが, 肉芽腫は残存していた。 8 週間後の同年 5 月は前回 受診時と比較して咽喉不快感には改善がなく肉芽腫 も不変であり（図 1 d)，セラペプターゼも効果が ないものと考えられ, 和漢診療学的所見では初診時 の腹候がそのまま残存していた。そこで『勿誤薬室 方価口訣』に「此の方は四逆散の変方にて所謂痃癖 労を為す者に効あり。」と記載されている解労散に 転方した ${ }^{6)}$ 。転方後 1 週間程度で咽喉頭異常感をほ とんど感じなくなり，4週間後には消失していた。 また同時に倦总感, 憂鬱, 焦燥, 手足の冷え, 食欲 低下も消失した。腹候においても胸脇苦満, 心下㾂 鞕, 腹部動悸は消失し, 腹直筋緊張と左季肋部〜左 側腹部にかけての左側型鼓音を残すのみとなった。 また転方 2 週間後の同年 6 月の喉頭内視鏡検查でも 肉芽腫の消失が確認された (図 $1 \mathbf{e})$ 。以後も2007 年 2 月まで同方を続服し, 症状および肉芽腫の再発 はみられなかったため廃薬とした（図 $1 \mathbf{f}) 。$

\section{考案}

喉頭肉芽腫の治療は外科的切除が優先されてきた が術後の再発は47～92\%と高率であるとされ，プロ トンポンプ・インヒビター, トラニラスト内服, マ クロライドの少量持続内服療法やステロイド吸入な どが有効であるとされているが，いずれも確実な効 果をもたらすものではなく治療方針は確立していな

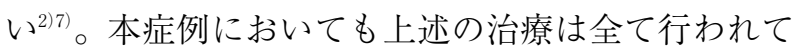
いたが，術後に 2 度の再発をみた。

本症例に対しては「㾦癖労を為す者」と考えて解 労散を投与した。痃癖とは「痃」は「臍の両傍が筋 張り盛り上がっていること」,「癖」は「両脇の間に 隠れた積塊のこと」, とされている ${ }^{8)}$ 。両側腹直筋緊 張，心下㾂鞕および両側胸脇苦満が著明であること から，「両脇の間に隠れた積塊」ととらえて痃癖と 考えた。また痃癖では本症例でみられたような消瘦, 食少, 疲労感などの全身症状を伴うとされているこ と $^{8}$, 長患いで体力が弱り, 回復しない状況を虚労 と考え解労散を投与した。原典である『楊氏家蔵 方』には「治虚労, 積気堅硬, 噎塞胸脇, 引背微

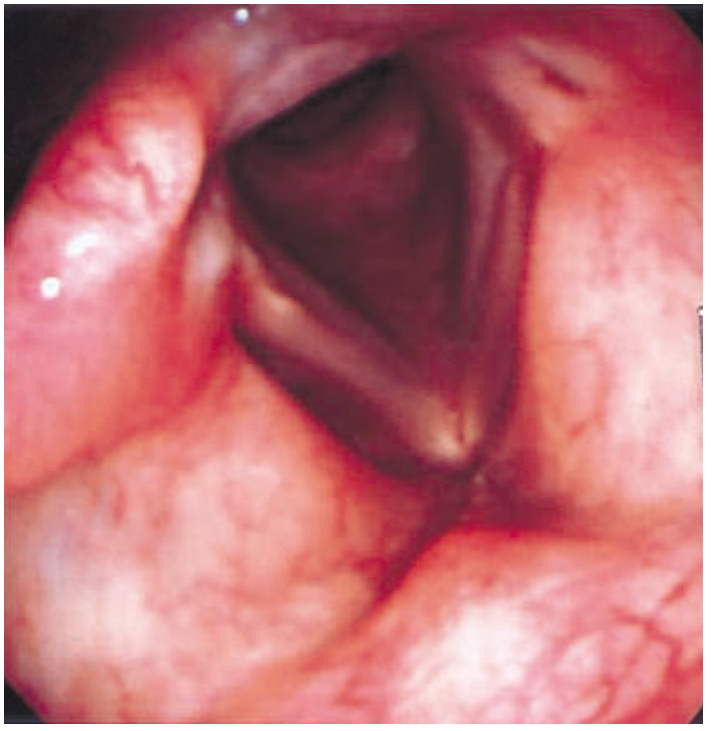

図 $1 f$

痛」と記載され ${ }^{9)}$ ，噎は『諸病源候論』に「気結す れば流れ宜しからず噎せしむ, 噎とは噎塞して通ぜ ざる也。とある ${ }^{10)}$ 。矢数道明はこの条文を気の滞 りのために腹中に塊を生じて心下部と胸脇全体が硬 く塞がったように緊張し，背に徹して痛むと解釈し

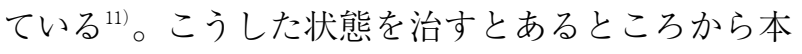
方は気を巡らす作用の強い方剂であることが分かる。

また藤平健・小倉重成は本方の目標について, 「少陽の虚証で, 右上腹部ないし側腹部にしばしば 強い痛みを感じ，衰弱して脱力間が強く，血色もま た悪く，臍の右斜上方四横指付近に抵抗と圧痛を認 めるか，または，ときには左右に軽度の胸脇苦満と 両腹直筋の緊張を認める場合の胆石症によいことが ある。と記載している ${ }^{12)}$ 。

これらの目標に加えて, 本症例での経験から倦总

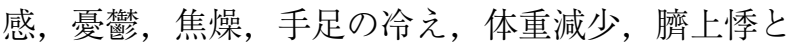
臍下悸, 上腹部を中心とする著明な鼓音の存在も解 労散を投与するうえでの目標になりうる可能性があ ると考えられた。

本症例においては初診時に四逆散を鑑別処方に挙 げながら四逆散の変方である解労散を想起するに到 るまで 4 カ月もの日時を要したことから, 日本漢方 の特徴である腹証を重視すべきであることを改めて 痛感した。

これまでの喉頭肉芽腫に対する漢方薬の治験報告 としては半夏厚朴湯 ${ }^{13)}$, 六君子湯 ${ }^{1415)}$ がある。半夏 厚朴湯は咽頭異常感による咳払いの頻度を下げるこ とで肉芽腫に対する刺激を和らげ消退を促し，六君 
子湯は胃食道逆流に効果があるとされていることか ら肉芽腫の消退を促したものと考察されている ${ }^{16)}$ 。 過去に報告のある半夏厚朴湯, 六君子湯および今回 提示した解労散では，いずれの方郕にも気を巡らす 作用のある生薬が配剤されている点が共通していた。 このことが今後の喉頭肉芽腫に対する漢方治療を考 えるうえで, 手がかりとなりうる可能性が示唆され た。

\section{附記}

本稿の症例にはツムラ半夏厚朴湯エキス $7.5 \mathrm{~g} /$ 日を 投与し, その後は柴药六君子湯, 桂姜雵草黄辛附湯, 解労散を煎薬で順次投与した。煎薬の構成と生薬集散 地は以下の通りである。

柴药六君子湯: 柴胡 $(4.0 \mathrm{~g}$, 中国), 人参 $(4.0 \mathrm{~g}$, 韓国), 白术 $(4.0 \mathrm{~g}$, 中国), 获苓 $(4.0 \mathrm{~g}$, 北朝鮮), 半夏 $(4.0 \mathrm{~g}$, 中国), 药薬 $(3.0 \mathrm{~g}$, 日本), 陳皮 $(2.0 \mathrm{~g}$, 日本), 大霖 $(2.0 \mathrm{~g}$, 中国), 生姜 $(1.0 \mathrm{~g}$, 中国), 甘 草 $(1.0 \mathrm{~g}$, 中国)

桂姜唻草黄辛附湯：桂皮 $(3.0 \mathrm{~g}$, 中国), 大霖 $(3.0$ $\mathrm{g}$, 中国), 甘草 $(1.0 \mathrm{~g}$, 中国), 麻黄 $(2.0 \mathrm{~g}$, 中国), 細辛 $(2.0 \mathrm{~g}$, 北朝鮮), 生姜 $(1.0 \mathrm{~g}$, 中国), 炮附子 $(0.5 \mathrm{~g}$, 中国)

解労散: 药薬 $(6.0 \mathrm{~g}$, 日本), 柴胡 $(4.0 \mathrm{~g}$, 中国), 土別甲 $(4.0 \mathrm{~g}$, 日本), 枳殼 $(4.0 \mathrm{~g}$, 中国), 甘草 $(2.0 \mathrm{~g}$, 中国), 获苓 $(6.0 \mathrm{~g}$, 北朝鮮 $)$, 大震 $(2.0 \mathrm{~g}$, 中国)，生姜（1.0g，中国）

\section{文献}

1) 広瀬 肇：われわれが経験した音声障害症例の統 計的観察. 音声障害の臨床，9-12，インテルナ 出版, 東京 (2000)

2 ) 兵頭政光, 田口亜紀, 小林丈二, 坂本 修: 喉頭 肉芽腫に対する治療戦略, 喉頭, 16, 102-105
(2004)

3 ) 長谷川弥人：柴药六君子湯. 勿誤薬室「方函」 「口訣」釈義, 563-564, 創元社, 大阪 (1994)

4 ) 長谷川弥人：桂姜霖草黄附湯. 勿誤薬室「方函」 「口訣」釈義, 432-434, 創元社, 大阪 (1994)

5 ) 矢数道明: 桂枝去药薬加麻黄附子細辛湯. 臨床応 用漢方処方解説, 133-138, 創元社, 大阪 (1997)

6 ) 長谷川弥人：解労散. 勿誤薬室「方函」「口訣」 釈義, 242, 創元社, 大阪 (1994)

7 ）角田晃一：喉頭肉芽腫，JOHNS， 21，1365-1368 (2005)

8 ）創医会学術部編：疾癖. 漢方用語大辞典, 316317, 燎原, 東京 (2001)

9 ) 柴田良治: 黑堂柴田良治処方集, 42, 黙堂会, 奈 良 (1989)

10) 牟田光一郎訳: 否噎病諸候. 校釈諸病源候論, 411-414，緑書房，東京 (1995)

11）矢数道明: 解労散. 臨床応用漢方処方解説, 644645，創元社，大阪 (1997)

12) 藤平 健, 小倉重成: 解労散. 漢方概論, 275 , 創元社，大阪 (1987)

13）市川朝也：喉頭の非特異性肉芽腫（特に特発性） 症例について, Prog. Med., 11, 3101-3106 (1991)

14）中村 毅, 三枝英人, 粉川隆行, 愛野威一郎, 岩 崎智治, 八木聰明: 六君子湯が有効であった非特 異的喉頭肉芽腫の 3 症例, 耳鼻咽喉科・頭頸部外 科, 76, 727-731 (2004)

15）和田倫之助, 浅井正嗣, 将積日出夫, 安村佐都紀, 十二町真樹子, 渡辺行雄, 嶋田 豊: 喉頭肉芽腫 に対する六君子湯の効果について, 耳鼻と臨床, 50, 338-343 (2004)

16）橋本邦夫, 杉山 貢, 国崎主税: 胃切除後逆流性 食道炎に対する六君子湯の効果, Prog. Med., 14, 2244-2246 (1994) 